\title{
Association between family dynamics and use of alcohol, tobacco, and other drugs by adolescents
}

\author{
Associação entre a dinâmica familiar e consumo de álcool, tabaco e outras drogas por adolescentes \\ Asociación entre la dinámica familiar y consumo de alcohol, tabaco y otras drogas por adolescentes
}

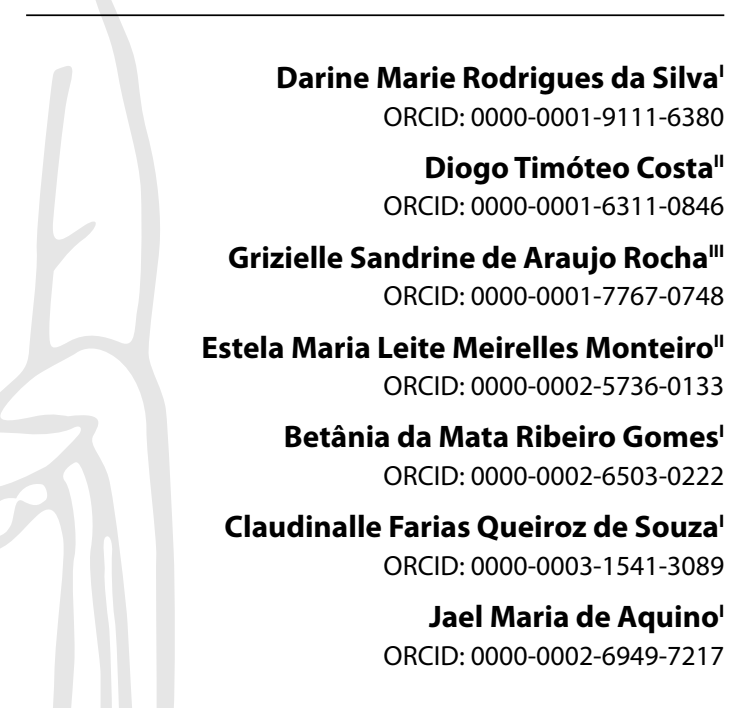

'Universidade de Pernambuco. Recife, Pernambuco, Brazil. "Universidade Federal de Pernambuco. Recife, Pernambuco, Brazil.

I'Fundação Oswaldo Cruz. Recife, Pernambuco, Brazil.

How to cite this article:

Silva DMR, Costa DT, Rocha GSA, Monteiro EMLM, Gomes BMR, Souza CFQ, et al. Association between family dynamics and use of alcohol, tobacco, and other drugs by adolescents. Rev Bras Enferm. 2021;74(3):e20200829. https://doi.org/10.1590/0034-7167-2020-0829

Corresponding author:

Darine Marie Rodrigues da Silva E-mail: darinemarie@gmail.com

EDITOR IN CHIEF: Antonio José de Almeida Filho ASSOCIATE EDITOR: Álvaro Sousa

\begin{abstract}
Objectives: to analyze, in the light of systemic thinking, the association between family dynamics and the use of alcohol, tobacco, and other drugs by adolescents throughout life. Methods: a cross-sectional descriptive study was conducted in nine public schools in the city of Recife. Three hundred and sixty-four adolescents aged 14 to 19 years participated. We used three questionnaires: The Alcohol, Smoking, and Substance Involvement Screening Test, a reduced version of the Drug Use Screening Inventory; and a sociodemographic questionnaire. Results: there was an association between parents/guardians ignoring what the child considers meaningful to him and the consumption of alcohol and tobacco by adolescents; we also verified an association between the occurrence of conflicting relationships and the consumption of illicit drugs by adolescents. Conclusions: it confirmed that disorganization in the family system, marked by impairments in emotional connections among members, and fragility in the sense of belonging are associated with the consumption of drugs in life by adolescents.
\end{abstract}

Descriptors: Adolescent; Illicit Drugs; Alcoholic Beverages; Tobacco; Family Relations.

\section{RESUMO}

Objetivos: analisar, à luz do pensamento sistêmico, a associação entre a dinâmica familiar e o consumo de álcool, tabaco e outras drogas na vida por adolescentes. Métodos: estudo descritivo transversal realizado em nove escolas públicas do Recife. Participaram 364 adolescentes com idade entre 14 a 19 anos. Foram utilizados três questionários: o Alcohol, Smoking and Substance Involvement Screening Test, uma versão reduzida do Drug Use Screening Inventory; e um questionário sociodemográfico. Resultados: houve associação entre pais/ responsáveis desconhecerem o que o filho considera importante para ele e o consumo de álcool e tabaco por adolescentes; também verificou-se associação entre ocorrência de relações conflituosas e o consumo de drogas ilícitas por adolescentes. Conclusões: foi evidenciado que a desorganização no sistema familiar, marcada por prejuízos nas ligações emotivas entre os membros, e a fragilidade no sentimento de pertença estão associadas ao consumo de drogas na vida pelos adolescentes.

Descritores: Adolescente; Drogas llícitas; Bebidas Alcoólicas; Tabaco; Relações Familiares.

\section{RESUMEN}

Objetivos: analizar, a la luz del pensamiento sistémico, la asociación entre la dinámica familiar y el consumo de alcohol, tabaco y otras drogas en la vida por adolescentes. Métodos: estudio descriptivo transversal realizado en nueve escuelas públicas de Recife. Participaron 364 adolescentes con edad entre 14 a 19 años. Fueron utilizados tres encuestas: el Alcohol, Smoking and Substance Involvement Screening Test, una versión reducida del Drug Use Screening Inventory; y una encuesta sociodemográfica. Resultados: hubo asociación entre padres/responsables desconocieron lo que su hijo considera importante y el consumo de alcohol y tabaco por adolescentes; también se verificó asociación entre ocurrencia de relaciones conflictivas y el consumo de drogas ilícitas por adolescentes. Conclusiones: fue evidenciado que la desorganización en el sistema familiar, marcada por perjuicios en las conexiones emotivas entre los miembros, y la fragilidad en el sentimiento de pertenecer están relacionadas al consumo de drogas en vida por los adolescentes.

Descriptores: Adolescente; Drogas llícitas; Bebidas Alcohólicas; Tabaco; Relaciones Familiares. 


\section{INTRODUCTION}

Adolescence is a period of life characterized by transformations related to physical, emotional, social, and psychological dimensions ${ }^{(1)}$. At this period, the onset of drug use may occur since a practice that interferes in adolescents' future ${ }^{(2)}$. The consumption of these substances is seen as a world health problem and a cause for concern for many countries ${ }^{(3)}$.

A study conducted in Nigeria, with 4,078 school adolescents, identifies that, in all geopolitical zones, alcohol consumption was more prevalent. Marijuana and other drugs were the most consumed substances in the Northwest, Northeast, and Central region of this country ${ }^{(4)}$. Accessibility and drug use by adolescents were also observed in a study conducted in Egypt ${ }^{(5)}$. Other Brazilian studies highlight social losses aimed at adolescents related to drug use ${ }^{(6-8)}$.

Given the complexity that involves drug use in adolescence, the family appears as a fundamental social core since it has the function of offering psychosocial protection and care to its children ${ }^{(9)}$. The education of individuals must take place in the household, where family members teach values so that these members are ready to live in a society ${ }^{(10)}$.

The family context has been pointed out as the potential protective or influencing aspect of drug use by adolescents ${ }^{(9)}$. We can consider that the socioeconomic situation may interfere with the protection that parents and guardians have with their children regarding drug use when there are risk situations such as insertion in a locality where there is easy access to drugs, low income, and difficulties in acquiring information and health education actions ${ }^{(11)}$.

Starting from the point of view that the family is a system in which its members constantly relate and it is in constant adaptation, we can say that adolescence may interfere in the family system, just as the family system may influence the adoption of certain practices and behaviors by adolescents ${ }^{(12)}$. In this perspective, we highlight the importance to look closely at the family since what happens to each member can be the result of their experience in the household ${ }^{(13)}$. Thus, the following guiding question of the study emerged: What factors present in the family dynamics are associated with the use of alcohol, tobacco, and other drugs by adolescents?

The study is based on systemic thinking, considering the complexity of the problem it analyzes the interaction between drug use in adolescence and family dynamics and its bidirectional. Thus, it is possible to recognize the factors that involve the family system that may be associated with exposure and maintenance of the vulnerable situation. Justify the study according to systemic thinking is differential since it allows a better understanding of the studied phenomenon. Therefore, through this approach, the study may subsidize the daily practice of nurses and other aspects of society since knowing these factors can assist the individual and collective intervention, whether within the family, religion, health, education, social assistance, or bodies for the protection of children and youth.

\section{OBJECTIVES}

To analyze, in the light of systemic thinking, the association between family dynamics and the use of alcohol, tobacco, and other drugs by adolescents throughout life.

\section{METHODS}

\section{Ethical aspects}

The present study followed the recommendations of Resolution No. 466/2012 of the Ministry of Health, which deals with the research with human beings. It received the approval of the Research Ethics Committee of the HUOC/PROCAPE Hospital Complex on April 9, 2018.

\section{Design, period and place of study}

It is a cross-sectional descriptive study, carried out according to Recommendations of Strengthening the Reporting of Observational Studies in Epidemiology (STROBE). It was conducted in nine public high school institutions, in a sanitary district of Recife, in the State of Pernambuco. Data collection occurred between April and July 2018.

\section{Population or sample; criteria of inclusion and exclusion}

The study population included 2,347 students enrolled in high school within the age range of 14 to 19 years of age, of both genders. The sample size was obtained through the sample calculation equation for the study of proportion in a finite population, corresponding to 330 students, and took into account the confidence level of $95 \%$, the margin of error of 0.05 , the expected proportion of 0.5 , and the total population of students. Considering a loss of $10 \%$, the minimum sample size was set to 364 students.

Data collection was performed in a stratified manner so that the number of students for each school was proportional to the number of students enrolled. We considered as an inclusion criterion to be a teenager in the age group of 14 to 19 years of age, of both genders, and to be enrolled in high school of the public institutions of the study. Students who had self-reported or mentioned cognitive deficit by management or faculty were excluded.

\section{Study protocol}

After the favorable opinion of the Research Ethics Committee, the team of researchers, previously trained, carried out the approach with the students during the intervals between classes, when they made a brief explanation about the study and the importance of their participation. At another moment, they were invited to participate in the study, delivering two copies of the Free and Informed Consent Term (TALE) to students under the age of 18. The TALE was properly explained, and one copy was delivered to the parents or guardians, and the other had to be returned completed and signed if they authorized it.

On the days scheduled for data collection, students aged 18 and over, as well as those aged under 18 who brought the TALE completed and signed by their parents or guardians participated in the survey. Students aged 18 years and over read and signed the Informed Consent Form (TCLE), and those aged under 18 years read and signed the Free and Informed Consent Term (TALE), in two copies, with one copy with the researchers, duly signed and completed. At this moment, the students individually filled the questionnaires in spaces reserved and made available by the institutions. 
In cases where the institutions, for structural reasons, could not offer this space, data collection was done in the classrooms, where only the students participating in the study remained. The researchers sought to ensure that this moment had as little interference as possible to ensure the secrecy of the data being collected. Students enrolled but not attending the classes did not participate in the study. For data collection, prior training was carried out to understand the instruments. During the entire collection period, no participants quit. In general, the study showed no losses related to the sample.

For the collection, the following instruments with multiplechoice questions were used: a reduced version of the Drug Use Screening Inventory (DUSI) containing area VI on the family system, the Alcohol, Smoking, and Substance Involvement Screening Test (ASSIST); and another prepared by the authors with sociodemographic questions.

ASSIST is an instrument built with the support of the World Health Organization (WHO) and was validated in Brazil in 2004(14). It provides knowledge about the use of drugs in life and the last three months by a person, as well as the recognition of various problems and the risk of using these substances. This instrument includes eight questions, despite only the data of the first question was used in this study, which refers to the use of drugs in life ${ }^{(14-15)}$.

DUSI is an instrument developed by Ralph Tarter ${ }^{(16)}$, a researcher at the University of Pittsburgh, validated in Brazil by De Micheli and Formigoni ${ }^{(17)}$. This instrument consists of 149 questions organized in ten areas: (I) substance use; (II) behavior pattern; (III) health status; (IV) psychiatric disorders; (V) social competence; (VI) family system; (VII) school adaptation; (VIII) adaptation to work; (IX) relationship with peers; and (X) leisure/recreation. Among these areas, VI was used in this study because it approaches the family system, contemplating 15 "Yes" or "No" questions ${ }^{(16-18)}$.

\section{Analysis of results and statistics}

The software Statistical Package for the Social Sciences (SPSS), version 21, performed the statistical analysis of the data. Qualitative variables were described based on absolute and percentage values. Qualitative variables were described based on absolute and percentage values. To verify the association of the family context, measured by the DUSI, with the use of tobacco, alcohol, and illicit drugs, measured by the ASSIST, we compared separately each of the 15 questions of the DUSI with the first question of the ASSIST - which measures whether the individual used alcohol, tobacco, and other drugs in life. We applied the Pearson chi-square test to make these comparisons and calculated the odds ratio (OR) and its respective $95 \%$ confidence intervals $(95 \% \mathrm{Cl})$ to describe the association's intensity. Results with descriptive levels below 0.05 were considered statistically significant.

\section{RESULTS}

Given the results found, we verified that the largest number of participating students were female (58.5\%), declared themselves brown (51.4\%), had school failures (55.8\%), lived in the urban area $(91.8 \%)$, did not work (79.4\%), had family income equal to a minimum wage $(44.8 \%)$, said to follow the Christian religion
(43.7\%), had single parents (41.8\%), their mother's highest level of education was complete high school (26.9\%) and their father's incomplete high school (25\%).

Regarding the frequency of drug use in life, we found that the most consumed substance by the participants was alcoholic beverage (61.8\%), followed by marijuana (17\%), tobacco derivatives (12.6\%), inhalants (6\%), cocaine/crack (2.5\%), hypnotics/ sedatives $(2.5 \%)$, hallucinogens $(2.2 \%)$, amphetamines or ecstasy $(0.8 \%)$ and other substances $(0.8 \%)$.

Regarding the family system, we could observe that the largest number of participants reported not having any family member arrested in the last year (88.3\%), denied ignorance of parents about what their children like or do not like (79.2\%), denied lack of clear rules at home about what they can or cannot do (79.2\%), reported not having frequent discussions with parents or guardians that involved shouting and screaming (78.3\%), did not report alcohol use by (64.2\%). However, 59\% reported alcohol, marijuana, or cocaine use in the last year by some family member (father, mother, brother, sister), and 55.8\% denied that the family hardly does things together.

Furthermore, it was evident that the highest percentage of participants reported: not feeling danger at home (96.2\%), no feeling of irritability (87.6\%), not having the feeling that parents or guardians do not care or take care of him (86.8\%), that there are no frequent arguments between parents or guardians (83.7\%), are not unhappy about the place in which they live (78.5\%), parents' unawareness about where their children are and what they are doing (77.4\%), there is no absence of parents for a long time (73.3\%). However, 50.8\% recorded the lack of knowledge of parents or guardians about what their children think or feel about what is important to them.

Regarding the analysis of the association between the variables of the DUSI with the use of the drug in life, we found statistically significant the use of tobacco in regards to the fact that the parents are not fully aware of what the child thinks and feels about things that are important to $\operatorname{him}(\mathrm{OR}=1.77 ; \mathrm{Cl} 95 \%=1.01-3.35$; $\mathrm{p}=0.046$ ) and parents or caregivers often don't know where their child is or what he is doing $(\mathrm{OR}=2,03 ; \mathrm{Cl} 95 \%=1.04-3.94$; $p=0.034)$. Thus, most of the participants who claimed to have these family problems were allocated among those who claimed to have already used tobacco in life (Table 1).

The use of alcohol in their life was associated to the fact that the family, hardly ever do things together $(\mathrm{OR}=1.57 ; \mathrm{Cl} 95 \%=$ $1.02-2.42 ; p=0.039)$, parents or guardians are not fully aware of what the child really thinks and feels about things that are important to $\operatorname{him}(\mathrm{OR}=1.61 ; \mathrm{Cl} 95 \%=1.05-2.47 ; \mathrm{p}=0.028)$, there are frequent arguments with the parent or guardian that involve the sounds of screaming and yelling (OR = 1.95; $\mathrm{Cl} 95 \%$ $=1.12$ - 3.39; $\mathrm{p}=0.016$ ), the individual has a family member who has consumed alcohol, marijuana, or cocaine in the last year (OR $=1.73 ; \mathrm{Cl} 95 \%=1.12-2.66 ; \mathrm{p}=0.013)$, be mad sometimes (OR $=2.25 ; \mathrm{Cl} 95 \%=1.20-4.23 ; \mathrm{p}=0.010)$; the parents or guardians are away most of the time $(\mathrm{OR}=2.13 ; \mathrm{Cl} 95 \%=1.27-3.56 ; \mathrm{p}=$ 0.004), parents or caregivers often do not know where their child is or what he is doing $(\mathrm{OR}=2.28 ; \mathrm{Cl} 95 \%=1.31-3.7 ; \mathrm{p}=0.003)$, the parents or guardians are not fully aware of what the child likes and does not like $(\mathrm{OR}=1.99 ; \mathrm{Cl} 95 \%=1.28-3.11 ; \mathrm{p}=0.002)$. 
Table 1 - Association between family dynamics and drug use by school adolescents in Recife, Pernambuco, Brazil, 2018

\begin{tabular}{|c|c|c|c|c|c|c|c|c|c|}
\hline \multirow{3}{*}{ DUSI } & \multicolumn{9}{|c|}{ Q1 ASSIST - In your life, you have already made use of... } \\
\hline & \multicolumn{3}{|c|}{ Tobacco } & \multicolumn{3}{|c|}{ Alcohol } & \multicolumn{3}{|c|}{ Illicit drugs } \\
\hline & $\begin{array}{l}\text { No } \\
(\%)\end{array}$ & $\begin{array}{l}\text { Yes } \\
(\%)\end{array}$ & $\boldsymbol{p}$ & $\begin{array}{l}\text { No } \\
(\%)\end{array}$ & $\begin{array}{l}\text { Yes } \\
(\%)\end{array}$ & $\boldsymbol{p}$ & $\begin{array}{l}\text { No } \\
(\%)\end{array}$ & $\begin{array}{l}\text { Yes } \\
\text { (\%) }\end{array}$ & $\boldsymbol{p}$ \\
\hline Have any members of your family used alcohol, marijuana, or cocaine in the last year? & 57.4 & 69.6 & 0.117 & 50.7 & 64.0 & $0.013^{*}$ & 57.1 & 66.2 & 0.155 \\
\hline $\begin{array}{l}\text { Did any of your family members use alcohol that caused trouble at home, at work, } \\
\text { or with friends? }\end{array}$ & 34.1 & 47.8 & 0.069 & 31.9 & 38.2 & 0.221 & 34.9 & 39.2 & 0.497 \\
\hline Have any members of your family been arrested in the last year? & 11.4 & 13.3 & 0.710 & 10.9 & 12.2 & 0.710 & 10.1 & 17.6 & 0.076 \\
\hline $\begin{array}{l}\text { Have you had frequent arguments with your parents or guardians that involve } \\
\text { shouting and screaming? }\end{array}$ & 20.8 & 28.3 & 0.248 & 15.1 & 25.8 & $0.016^{*}$ & 18.6 & 33.8 & $0.005^{*}$ \\
\hline Does your family hardly do things together? & 43.1 & 52.2 & 0.246 & 37.4 & 48.4 & $0.039^{*}$ & 42.4 & 51.4 & 0.167 \\
\hline Do your parents or guardians ignore what you like and do not like? & 41.0 & 53.3 & 0.118 & 32.4 & 48.9 & $0.002^{*}$ & 39.6 & 54.1 & $0.025^{*}$ \\
\hline In your home, do you miss any clear rules about what you can or cannot do? & 20.6 & 22.2 & 0.798 & 16.7 & 23.3 & 0.130 & 20.1 & 23.3 & 0.554 \\
\hline $\begin{array}{l}\text { Do your parents or guardians ignore what you think or feel about the things that } \\
\text { are important to you? }\end{array}$ & 49.1 & 63.0 & $0.046^{*}$ & 43.5 & 55.4 & $0.028^{*}$ & 49.3 & 56.8 & 0.253 \\
\hline Do your parents or guardians often argue? & 16.1 & 17.8 & 0.781 & 12.4 & 18.8 & 0.114 & 14.5 & 23.6 & 0.062 \\
\hline Are your parents or guardians often ignore where you are or what you are doing? & 20.8 & 34.8 & $0.034^{*}$ & 14.4 & 27.7 & $0.003^{*}$ & 20.8 & 29.7 & 0.101 \\
\hline Are your parents or guardians away most of the time? & 25.4 & 35.6 & 0.149 & 18.1 & 32.0 & $0.004^{*}$ & 25.2 & 32.4 & 0.208 \\
\hline Do you feel that your parents do not care or do not take care of you? & 12.6 & 17.4 & 0.375 & 9.4 & 15.6 & 0.086 & 11.4 & 20.5 & $0.039^{*}$ \\
\hline Are you unhappy about the place you live in? & 20.2 & 30.4 & 0.114 & 18.7 & 23.2 & 0.309 & 19.7 & 28.4 & 0.106 \\
\hline Do you feel in danger at home? & 4.1 & 2.2 & 0.528 & 2.2 & 4.9 & 0.188 & 3.8 & 4.1 & 0.917 \\
\hline Do you get angry sometimes? & 87.4 & 89.1 & 0.742 & 82.0 & 91.1 & $0.010^{*}$ & 88.3 & 85.1 & 0.464 \\
\hline
\end{tabular}

Note: DUSI - Drug Use Screening Inventory; * $p<0.05$.

For illicit drugs in life, there was an association regarding the fact that the adolescent felt that the parents or guardians do not care or do not care for him $(\mathrm{OR}=2.01 ; 95 \% \mathrm{Cl}=1.03-3.95 ; \mathrm{p}$ $=0.039$ ); parents or guardians who do not know what the child likes and dislikes $(\mathrm{OR}=1.79 ; 95 \% \mathrm{Cl}=1.07-3.00 ; \mathrm{p}=0.025)$; and had frequent discussions with screaming and screaming $(\mathrm{OR}=$ $2.23 ; 95 \% \mathrm{Cl}=1.27-3.92 ; \mathrm{P}=0.005)$. To this end, adolescents who have already used illicit drugs in their lives reported frequent arguments involving screams and shouts with parents or guardians, stated that their parents or guardians do not care or do not care for him and that the parents or guardians do not know what he likes and what he does not like (Table 1).

\section{DISCUSSION}

The present study identified that aspects related to fragilities in the relationship between family members were associated with the use of tobacco, alcoholic beverages, and illicit drugs. Among these fragilities, conflicting relations were associated with the use of alcoholic beverages and illicit drugs. Also, the presence of a family member who consumed alcohol, marijuana, or cocaine in the last year was associated with the consumption of alcoholic beverages.

As verified in the present study, research conducted in Egypt confirms that family conflicts are factors that increase the chances of adolescents going to the streets in search of drugs since their use is as an escape from reality due to the state of euphoria and numbness caused by their use ${ }^{(5)}$. In general, early drug use affects adolescent development, as it imposes higher risks of harm in the various dimensions: physical, mental, social, and family ${ }^{(19)}$.
Regarding the use of tobacco and alcoholic beverages in adolescence, we can say that this practice is capable of causing harm that affects the adolescents' health and may accompany them throughout life due to the risk of acquiring chronic non-communicable diseases ${ }^{(20)}$. Marijuana is also another substance that causes a lot of damage to teenagers since the low cost and easy access are the factors that make this drug is preferable compared to other illicit drugs ${ }^{(21)}$.

A study conducted with adolescents from Minnesota reveals that the adolescent habit of drinking between peers may be more associated with influence than with the selection of friends, highlighting the importance of programs to prevent the use of alcohol and other drugs that allow younger adolescents to discern to resist peer influences ${ }^{(22)}$.

Many factors can influence adolescents concerning drug use. However, such factors are aggravated when there is no protective effect of parents or guardians about their children, according to a study that considered tobacco use by adolescents ${ }^{(23)}$. Thus, we should note that poor parental monitoring and poor quality in the relationship between parents and children facilitate the practice of habits that compromise the physical, mental and emotional integrity of adolescents ${ }^{(24-25)}$.

Starting from the idea that the family is a system, we consider that the behavior of one of its members can be explained by the dynamics in which they are inserted. In this perspective, the quality of the relationship among parents and children influences family conflict formation. However, an open and flexible family relationship can contribute positively to solving internal problems by recognizing the adolescent as a member able to participate in family decisions because there is an environment in which he/she is legitimized, with his/her beliefs, thoughts, and feelings. Therefore, the importance of 
relationships and reciprocity among family members is emphasized in a systemic context according to scholars' suggestions ${ }^{(13,25)}$.

The use of alcohol, marijuana, or cocaine by family members was associated with the lifetime use of alcoholic beverages by the adolescents that participated in the survey. Similarly, a study conducted in a Psychosocial Care Center for Childhood and Adolescence (CAPSia) in the State of Rio Grande do Sul shows that, of the patients treated by this service, $56.8 \%$ reported living with a family member who used drugs ${ }^{(7)}$. This fact reveals that, depending on the attitudes of family members, the family context can be seen as a risk factor, when it should constitute a protective factor to the use of drugs by adolescents ${ }^{(12,24)}$.

The present study showed that factors such as frequent arguments with parents, family members who hardly meet to perform activities, lack of dialogue between parents and children, and even limitations of parents or guardians to educate and protect children potentiate the adolescents' exposure to risk situations. A study shows that aspects related to family dynamics may impact drug use by adolescents since the family is responsible for the healthy growth process of its members ${ }^{(26)}$.

It is a fact that the interactions existing in the family environment can define the quality of the relationship, considering the emotional, affective, and communication connections between the family members important factors that can protect or offer risk to drug use ${ }^{(26)}$. To this end, research carried out in California revealed family strengthening as a factor capable of protecting adolescents since families with higher values of family strengthening had adolescents who consumed fewer alcoholic beverages ${ }^{(27)}$.

However, fights between family members can drive adolescents to seek new sensations that harm their lives as a form of compensation. By framing it in such a context, we understand that this period is the most dangerous, given the difficulty of measuring the danger in the face of the exploitation of new pleasures by developing individuals ${ }^{(24,28)}$. Due to the fragility of family ties, adolescents may adopt practices that possibly lead to social exclusion and disengagement in other areas of life, including in the school context ${ }^{(8)}$.

Thus, a crisis involving the family system must be seen not only on the negative side, for achieving family homeostasis, but also on the positive side, because, through the system's ability to restore itself, it becomes able to build new ways of acting and living while preserving the unity of the group ${ }^{(29)}$. We can achieve family restructuring by adjusting the perspectives of its members and changes in their conduct. This process is permeated by adding higher value to attitudes and feelings that favor family interactions, such as affectivity and attention ${ }^{(30)}$.

Thus, parents must adopt behaviors that favor protection against drug use by adolescents, for example, being present and establishing communication with their children. It is valid because, for adolescents, the presence of parents is one of the necessary foundations for integral and healthy development ${ }^{(12)}$. Family support is also essential for those adolescents who need to undergo treatment in Alcohol and Drug Psychosocial Care Centers (CAPS ad), as this aspect favors the adherence ${ }^{(31)}$.

Through systemic thinking, it is possible to clearly understand the health problems that affect the members of the system because by understanding the circularity of this structure, we can say that the behavior of one member interferes with the others while receiving influence from them ${ }^{(29)}$. In the field of health, systemic thinking brings relevant contributions since, when considering the individual and his context, it reinforces the importance of the integrality of care in the various levels of health care, and it highlights the need for the use of new methodologies that cover health from a broadened point of view ${ }^{(32)}$.

By looking at the individual separately, we cannot understand the whole family system; thus, erroneous interventions may happen. Therefore, respecting the family as a whole is essential for understanding how a particular problem affects everyone and how everyone reacts. When considering the instability of a system, health professionals should be aware that, even if they do not have control over the thoughts and attitudes of individuals, they have the fundamental role of contributing to the resolution of family issues through a joint response ${ }^{(29)}$.

Nursing can collaborate through health promotion and prevention interventions that seek to raise awareness about the harm caused by the use of alcohol, tobacco, and other drugs that affect the adolescent's biopsychosocial domain and family dynamics. It is essential to include the family as a focus of intervention to ensure the effectiveness of these actions since its participation in prevention and recovery can not only increase the empowerment of adolescents in overcoming challenges but also be a support network that helps them in the control of consumption ${ }^{(33-34)}$.

\section{Limitations of the study}

A limitation was the study carried out only with students from public schools located in a sanitary district in vulnerable conditions, which does not allow generalization to other groups of adolescents who reside in different locations and study in private educational institutions. Also, limitations may be seen as the study approach, which was only quantitative; and the analysis perspective, which did not allow to consider the participation of the family due to the time stipulated for the study.

\section{Contributions to the fields of Nursing, Health or Public Policy}

By presenting an approach on the family factors associated with drug use by school adolescents from the perspective of systemic thinking, this study allows a better understanding of the context that involves drug use by this group. In this perspective, it can contribute to the praxis of health professionals, especially nurses, by providing subsidies for the implementation of actions aimed at health promotion. Also, it provides evidence that can guide the development of intersectoral actions and strategies aimed at promoting the mental health of adolescents, considering the family as a fundamental axis for the implementation of these actions.

\section{CONCLUSIONS}

The results showed the association of variables of the family context with the use of tobacco, alcoholic beverages, and illicit drugs in the adolescents'lives. In this sense, conflicts in the family system resulting from fragilities in emotional ties and the feeling of belonging among members were associated with drug use in life.

Among the variables of the family system analyzed, it was possible to highlight the association of "use of alcoholic beverages 
and tobacco in life" with the "ignorance of parents or guardians about what the child considers important for him." As for the use of illicit drugs, it was possible to highlight that the adolescents had experienced frequent arguments with their parents or guardians that involved screams and shouts.

By considering the family as a system, it was possible to understand the association between drug use by adolescents and variables of the family system, and this allows us to infer that such a problem may also be interfering with the harmony of the family system because an issue that affects a family member may reflect in the whole family, and an issue that affects the family is felt by the members individually as well.

Therefore, we emphasize the importance that health professionals, especially nurses, recognize health problems through a systemic view focusing on the family. Also, it strengthens the practice of health promotion activities as an effective tool in the care of adolescents, centered on the family and for the homeostasis of the family system. Furthermore, this study encourage the execution of others that consider the participation of the family and the qualitative approach with a view to providing a greater understanding of the phenomenon studied.

\section{FUNDING}

This research was funded by the Universidade de Pernambuco and Coordenação de Aperfeiçoamento de Pessoal de Nível Superior (CAPES, Coordination for the Improvement of Higher Education Personnel).

\section{REFERENCES}

1. World Health Organization (WHO). Launch: a Lancet Commission on adolescent health and wellbeing [Internet]. Geneva: WHO; 2019[cited 2020 Oct 13]. Available from: https://www.who.int/life-course/news/events/adolescent-health-lancet-papers/en/

2. Ribas T, Gehlen MH, Ventura J, Paula SF, Ferreira CL, Pereira AD. Drug initiation and abuse during adolescence: a narrative review. Rev Pesqui. 2018;10(4):1169-75. https://doi.org/10.9789/2175-5361.2018.v10i4.1169-1175

3. World Health Organization (WHO). Adolescentes: riesgos para la salud y soluciones [Internet]. Geneva: WHO. 2019[cited 2019 Dec 10]. Available from: https://www.who.int/es/news-room/fact-sheets/detail/adolescents-health-risks-and-solutions

4. Taglianti-Vigna F, Alesina M, Damjanovic L, Mehanovic E, Akanidomo I, Pwajok J, et al. Knowledge, attitudes and behaviors on tobacco, alcohol and other drugs among Nigerian secondary school students: differences by geopolitical zones. Drug Alcohol Rev. 2019;38(6):712-24. https://doi. org/10.1111/dar.12974

5. Loffredo CA, Boulos DNK, Doa'a AS, Jilson IA, Garas M, Loza N, et al. Substance use by Egyptian youth: current patterns and potential avenues for prevention. Subst Use Misuse. 2015;50:609-18. https://doi.org/10.3109/10826084.2014.997391

6. Soares FRR, Farias BRF, Monteiro ARM. Consumption of alcohol and drugs and school absenteeism among high school students of public schools. Rev Bras Enferm. 2019;72(6):1692-8. https://doi.org/10.1590/0034-7167-2018-0828

7. Bittencourt ALP, França LG, Goldim JR. Vulnerable adolescence: bio-psychosocial factors related to drug use. Rev Bioét. 2015;23(2):308-16. https://doi.org/10.1590/1983-80422015232070

8. Galhardi CC, Matsukura TS. O cotidiano de adolescentes em um Centro de Atenção Psicossocial de Álcool e outras Drogas: realidades e desafios. Cad Saúde Pública. 2018;34(3):e00150816. https://doi.org/10.1590/0102-311x00150816

9. Cardoso AMR, Dytz JLG, Lima MG. Contexto familiar de adolescentes em medida socioeducativa: fortalecimento do potencial protetivo. Comun Ciênc Saúde [Internet] 2016 [cited 2019 Nov 13];27(4):279-90. Available from: http://bvsms.saude.gov.br/bvs/periodicos/ccs_artigos/contexto_ familiar_adolescentes.pdf

10. Barreto MJ, Rabelo AA. A família e o papel desafiador dos pais de adolescentes na contemporaneidade. Pensando Fam [Internet]. 2015 [cited 2020 Oct 11];19(2):34-42. Available from: http://pepsic.bvsalud.org/scielo.php?script=sci_arttext\&pid=S1679-494X2015000200004

11. Oliveira ELB, Bittencourt LP, Carmo AC. A importância da família na prevenção do uso de drogas entre crianças e adolescentes: papel materno. Rev Eletrôn Saúde Mental Alcool Drog [Internet]. 2008 [cited 2019 Nov 15];4(2):1-16. Available from: http://pepsic.bvsalud.org/ scielo.php?script=sci_arttext\&pid=S1806-69762008000200003

12. Zappe JG, Dapper F. Drogadição na adolescência: família como fator de risco ou proteção. Rev Psicol IMED. 2017;9(1):140-58. https://doi. org/10.18256/2175-5027.2017.v9i1.1616

13. Bousso RS. A teoria dos sistemas familiares como referencial para pesquisas com famílias que experienciam a doença e a morte. Rev Min Enferm [Internet] 2008 [cited 2019 Dec 19];12(2):257-61. Available from: http://www.reme.org.br/artigo/detalhes/266

14. Henrique IFS, Micheli D, Lacerda RB, Lacerda LA, Formigoni MLOS. Validação da versão brasileira do teste de triagem do envolvimento com álcool, cigarro e outras substâncias (ASSIST). AMB Rev Assoc Med Bras. 2004;50(2):199-206. https://doi.org/10.1590/ S0104-42302004000200039

15. World Health Organization (WHO). The Alcohol, Smoking and Substance Involvement Screening Test (ASSIST) [Internet]. Geneva; 2010 [cited 2019 Jan 01]. Available from: https://www.who.int/publications/i/item/978924159938-2

16. Tarter RE. Evaluation and treatment of adolescent substance abuse: a decision tree method. Am J Drug Alcohol Abuse. 1990;16(1-2):1-46. https://doi.org/10.3109/00952999009001570 
17. Micheli D, Formigoni MLOS. Psychometric Properties of the Brazilian Version of the Drug Use Screening Inventory. Alcohol Clin Exp Res. 2002;26(10):1523-8. https://doi.org/10.1097/01.ALC.0000033124.61068.A7

18. Micheli D, Formigoni MLOS. Screening of drug use in a teenage Brazilian sample using the Drug Use Screening Inventory (DUSI). Addict Behav. 2000;25(5):683-91. https://doi.org/10.1016/s0306-4603(00)00065-4

19. Conceição MIG, Ventura CA. Perception of risks and benefits associated with the use of cannabis among students in Brasilia, Brazil. Texto Contexto Enferm. 2019;28(Spe):e146. https://doi.org/10.1590/1980-265X-TCE-CICAD-14-6

20. Freitas EAO, Martins MSAS, Espinosa MM. Alcohol and tobacco experimentation among adolescents of the Midwest Region/Brazil. Ciênc Saude Colet. 2019;24(4):1347-57. https://doi.org/10.1590/1413-81232018244.15582017

21. Elicker E, Palazzo LS, Aerts DRGC, Alves GG, Câmara S. Use of alcohol, tobacco and other drugs by adolescent students from Porto Velho-RO, Brazil. Epidemiol Serv Saúde. 2015;24(3):399-410. https://doi.org/10.5123/S1679-49742015000300006

22. Sieving RE, Perry CL, Williams CL. Do friendships change behaviors, or do behaviors change friendships? examining paths of influence in young adolescents' alcohol use. J Adolesc Health. 2000;26(1):27-35. https://doi.org/10.1016/S1054-139X(99)00056-7

23. Albuquerque JM, Blanco ATM, Vallois RM, Peregrino AAF. The factors that influence the teenage cigarette consumption and its degree of dependency. Rev Pesqui. 2016;8(2):4518-25. https://doi.org/10.9789/2175-5361.2016.v8i2.4518-4525

24. Moradi P, Lavasani FF, Dejman M. Adolescent substance abuse and family environment: a qualitative study. Int J High Risk Behav Addict. 2019;8(2):e83781. https://doi.org/10.5812/ijhrba.83781

25. Hemati Z, Abbasi S, Oujian P, Kiani D. Relationship between parental communication patterns and self-efficacy in adolescents with parental substance abuse. Iran J Child Neurol [Internet] 2020 [cited 2020 Jun 08];14(1):49-56. Available from: https://www.ncbi.nlm.nih.gov/pmc/ articles/PMC6956959/

26. Nimtz MA, Tavares AMF, Maftum MA, Ferreira ACZ, Borba LO, Capristano FC. Impacto do uso de drogas nos relacionamentos familiares de dependentes químicos. Cogitare Enferm [Internet] 2014 [cited 2019 Dec 26];19(4):667-72. Available from: http://revistas.ufpr.br/cogitare/ article/view/35721/23905

27. Ewing BA, Osilla KC, Pedersen ER, Hunter SB, Miles JNV, D'amico EJ. Longitudinal family effects on substance use among an at-risk adolescent sample. Addict Behav. 2015;41:185-91. https://doi.org/10.1016/j.addbeh.2014.10.017

28. Nascimento MO, Moreira A, Poffal ALM, Souza FB, Avallone DM. Influência parental na educação escolar adolescente. Adolesc Saúde [Internet] 2017 [cited 2019 Dec 27];14(2):135-43. Available from: http://www.adolescenciaesaude.com/detalhe_artigo.asp?id=658

29. Horta ALM, Fernandes H. Family and crisis: contributions of the systemic thinking for family care. Rev Bras Enferm. 2018;71(2):234-5. https:// doi.org/10.1590/0034-7167.2018710201

30. Barbosa DC, Sousa FGM, Leite JL. Scoring interventions in family relations regarding the care for the child with a chronic condition. Texto Contexto Enferm. 2015;24(1):87-95. https://doi.org/10.1590/0104-07072015001820013

31. Gonçalves JRL, Canassa LW, Cruz LC, Pereira AR, Santos DM, Gonçalves AR. Adherence to treatment: perception of adolescents in chemical dependency. Rev Eletrôn Saúde Mental Álcool Drog. 2019;15(1):57-63. https://doi.org/10.11606/issn.1806-6976.smad.2019.000415

32. More CLOO, Crepaldi MA, Gonçalves JR, Menezes M. Contribuições do pensamento sistêmico à prática do psicólogo no contexto hospitalar. Psicol Estud [Internet]. 2009 [cited 2019 Dec 28];14(3):465-73. Available from: http://www.scielo.br/pdf/pe/v14n3/v14n3a07.pdf

33. Alonso-Castillo MM, Yañez-Lozano Á, Armendáriz-García NA. Funcionalidad familiar y consumo de alcohol em adolescentes de secundaria. Salud Drogas. 2017;17(1):87-96. https://doi.org/10.21134/haaj.v17i1.286

34. Latipun L, Karindra AP, Hasanati N. Family and cognitive integrative treatment to prevent relapse of substance abuse among adolescents in Indonesia. Mediter J Clinl Psychol. 2019;7(2):1-12. https://doi.org/10.6092/2282-1619/2019.7.2133 